\title{
PENGEMBANGAN TES KELINCAHAN TENDANGAN PENCAK SILAT
}

\section{DEVELOPMENT OF PENCAK SILAT KICKING ABILITY TEST}

\author{
Syarif Hidayat ${ }^{1}$, Arief Ibnu Haryanto ${ }^{2}$ \\ ${ }^{1}$ Jurusan Pendidikan Kepelatihan Olahraga, Fakultas Olahraga dan Kesehatan \\ Universitas Negeri Gorontalo \\ ${ }^{2}$ Program Studi Ilmu Keolahragaan, Fakultas Keguruan dan Ilmu Pendidikan, \\ Universitas Muhammadiyah Gorontalo \\ Kontak Penulis: syarif_hidayat@ung.ac.id
}

\begin{abstract}
ABSTRAK
Penelitian ini bertujuan untuk mengembangkan tes kelincahan tendangan Pencak silat. Penelitian ini merupakan penelitian dan pengembangan. Penelitian ini melalui tahapan pengumpulan informasi, perencanaan informasi, mengembakngkan produk awal, uji coba awal, revisi untuk menyusun produk utama, uji coba lapangan, revisi untuk menyusun produk operasional, uji coba produk operasional produk final, revisi produk final, diseminasi dan implementasi produk. Subjek penelitian ujicoba kelompok kecil sebanyak 15 atlet Pencak silat yang aktif berlatih di PPLP Gorontalo dan ujicoba kelompok besar sebanyak 30 pesilat yang terdiri dari beberapa perguruan Pencak silat yang aktif di Kota Gorontalo. Analisis data merupakan data kuantitatif yang dikonversi menjadi data deskriptif kuantitatif menggunakan uji korelasi pearson. Hasil penelitian dan pengembangan ini sebuah model tes tes kelincahan tendangan Pencak silat yang diberi nama T-Test TPS. Data hasil validasi ahli 100\% menyatakan layak. Hasil ujicoba kelompok kecil dapat diperoleh data catatan waktu tercepat adalah 11,19 detik dan terendah 13,60 detik dengan jumlah rata-rata sebesar 12,58 dan hasil ujicoba kelompok besar dapat diperoleh data catatan waktu tercepat adalah 11,32 detik dan terendah 13,98 detik dengan jumlah rata-rata sebesar 12,43. Ujicoba kelompok besar diperoleh hasil reliabilitasnya $\mathrm{r}=0,96$ dengan demikian dapat dikatakan bahwa model tes ini dikatakan reliabel.
\end{abstract}

Kata kunci: pengembangan, tes kelincahan, tendangan, Pencak silat

\begin{abstract}
This study aims to develop a Pencak silat kick agility test. This research is research and development. This research went through the stages of collecting information, planning information, developing initial products, initial trials, revisions to compose the main product, field trials, modifications to compile operational products, final product functional products, final product revisions, dissemination, and product implementation. The subjects of the small group trial were 15 Pencak silat athletes who were actively practicing at PPLP Gorontalo, and the large group trial consisted of 30 fighters consisting of several martial arts colleges active in Gorontalo City. Data analysis is quantitative data that is converted into quantitative descriptive data using the Pearson correlation test. This research and development result is a test model for the agility test of Pencak silat kicks, which is named T-Test TPS. The data from the expert validation results are $100 \%$ eligible. The results of small group trials can be obtained that the fastest time record data is 11.19 seconds and the lowest is 13.60 seconds with
\end{abstract}


an average number of 12.58 and the results of large group trials can be obtained that the fastest time record data is 11.32 seconds and the lowest is 13, 98 seconds with an average of 12.43. Large group trials received reliability results $r=0.96$; thus, this test model is said to be reliable.

Keywords: development, agility test, kick, Pencak silat

\section{PENDAHULUAN}

Pencak silat adalah olahraga beladiri yang didalamnya terdapat unsur serangan yang menggunakan kaki dan tangan serta belaan dan hindaran dalam memperoleh poin yang bertujuan untuk meraih kemenangan yang merupakan beladiri warisan nenek moyang Indonesia (Setiawan, 2011). Serangan pesilat harus teratur dan berangkai dengan berbagai cara atau teknik ke arah sasaran dengan tepat (Ediyono \& Widodo, 2019). Teknik serangan beruntun yang diperkenankan yaitu harus teratur berangkai dengan berbagai cara dalam arti yang tidak sejenis (Hausal et al., 2018). Komponen utama dalam serangan adalah "pukulan" (serangan dengan menggunakan tangan) (Saputra et al., 2018), dan "tendangan" (serangan dengan menggunakan kaki) (Subekti et al., 2020). Kajian dari analisis pertandingan dalam olahraga, teknik serangan pada olahraga Pencak silat yaitu teknik tendangan merupakan komponen yang paling dominan (Pomatahu, 2018). Pertandingan Pencak silat, tendangan mempunyai beberapa keuntungan, antara lain tendangan mempunyai nilai yang cukup tinggi yaitu dua, jangkauan serangan yang lebih panjang serta mempunyai power yang lebih tinggi bila dibandingkan dengan teknik serangan lainnya.

Seorang pesilat harus memilki kemampuan melesatkan tendangan ke sasaran yang sah pada lawan, sehingga sulit untuk dihindari lawan (Tofikin \& Sinurat, 2020). Kemampuan melakukan tendangan yang baik, dibutuhkan kualitas kecepatan (Harun et al., 2020) dan kelincahan (Trisnowiyanto, 2016). Kelincahan dalam Pencak silat adalah kemampuan merubah arah (berpindah tempat atau posisi) dalam menghindari serangan lawan dan dilanjutkan dengan serangan balasan baik tendangan, pukulan maupun tangkapan (Regency \& Sinurat, 2020). Pengukuran tendangan dalam Pencak silat harus dibutuhkan suatu tes yang valid dan reliabel (D. P. Saputro \& Siswantoyo, 2018). Tes kemampuan atlet Pencak silat yang valid dan reliabel masih sangat sulit ditemukan, khususnya untuk mengukur kualitas kelincahan tendangan pesilat dari segi tekniknya.

Penelitian terdahulu yang berkaitan dengan penelitian ini pernah dilakukan dengan judul penyusunan norma tes fisik Pencak silat remaja kategori tanding (D. P. Saputro \& Siswantoyo, 2018). Penelitian tersebut berfokus pada norma tes fisik remaja dengan menggunakan delapan item tes yang terdiri dari fleksibilitas, kecepatan, kekuatan lengan, kekuatan tungkai, kelincahan, power tungkai, daya tahan aerobik, dan daya tahan anaerobik. Penelitian tersebut hampir mirip dengan penelitian ini, namun tetap saja ada pembeda yang berkaitan dengan kelincahan yang diukur dari penelitian ini yaitu lebih ke teknik.

Penelitian lain yang berjudul penyusunan assessmen performa tendangan Pencak silat kategori tanding (Hariono et al., 2016). Penelitian tersebut merupakan penelitian yang berfokus pada tinjauan biomekanika tendangan Pencak silat kategori tanding, yang terdiri dari: tendangan depan, tendangan sabit, tendangan samping, dan tendangan belakang. Penelitian tersebut hampir mirip juga terhadap penelitian ini yang berfokus pada tendangan, namun penelitian ini lebih spesifik lagi karena meneliti tentang kelincahan tendangan Pencak silat. 
Tendangan dalam olahraga Pencak silat merupakan komponen yang paling dominan baik saat melakukan serangan maupun belaan (Diana, 2019) (Hidayat \& Kadir, 2020). Pada dasarnya untuk mengetahui bahwa tendangan tersebut mempunyai kualitas yang baik, dibutuhkan satuan alat ukur yang baku dan standar (Sayfei et al., 2020). Alat ukur untuk mengetahui kualitas tendangan belum ada standar baku serta norma penilaiannya. Dengan demikian belum adanya tolok ukur atau alat evaluasi yang digunakan sebagai panduan untuk melihat perkembangan dan peningkatan kemampuan tendangan sebagai wujud dari keberhasilan pencapaian program latihan sebagai akibatnya keberhasilan yang telah dicapai oleh atlet belum dapat terpantau dengan baik. Sehingga dengan adanya permasalahan tersebut peneliti tertarik untuk menciptakan suatu alat ukur kelincahan tendangan Pencak silat dengan melihat teknik tendangan yang sahih, handal, dan obyektif.

\section{METODE PENELITIAN}

Penelitian ini dilakukan di PPLP Provinsi Gorontalo dan Perguruan Pencak silat yang ada di Kota Gorontalo. Penelitian ini menggunakan metode penelitian dan pengembangan (Research and Development) merupakan metode penelitian yang digunakan untuk menghasilkan produk tertentu, dan menguji keefektifan produk tersebut. Penelitian pengembangan ini dilakukan untuk menghasilkan sebuah buku panduan pengembangan tes kelincahan tendangan Pencak silat.

Adapun pengembangan yang dilakukan dalam penelitian ini yaitu untuk menghasilkan model tes yang bertujuan untuk mengembangkan tes kelincahan tendangan Pencak silat yang dikemas dalam buku panduan tes kelincahan tendangan Pencak silat. Penelitian ini melalui tahapan pengumpulan informasi, perencanaan informasi, mengembakngkan produk awal, uji coba awal, revisi untuk menyusun produk utama, uji coba lapangan, revisi untuk menyusun produk operasional, uji coba produk operasional produk final, revisi produk final, diseminasi dan implementasi produk.

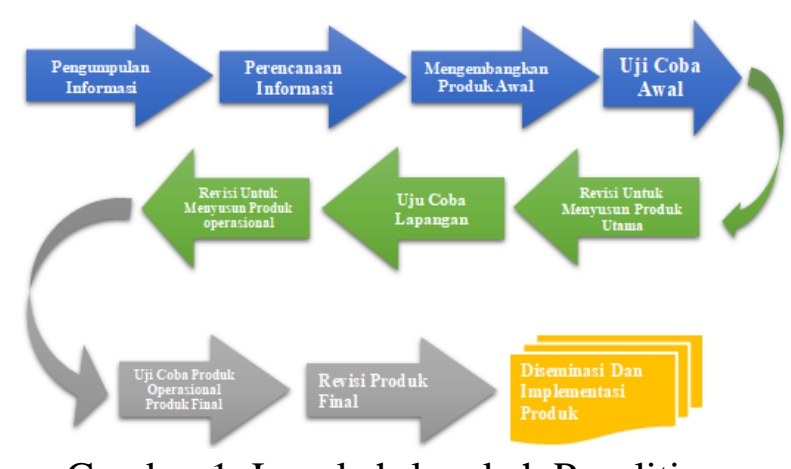

Gambar 1. Langkah-langkah Penelitian

Teknik analisis data yang digunakan yaitu analisis deskriptif kuantitatif dan kualitatif. Draf model latihan dinyatakan layak untuk di lakukan uji coba dalam skala kecil apabila para ahli/pakar telah memberikan validasi dan menyatakan semua item dianggap sesuai dengan cara memberi tanda $(\sqrt{ }$ ) dengan nilai 1 (satu) pada kolom sesuai. Namun jika ahli/pakar berpendapat bahwa item klasifikasi tidak sesuai cara memberi tanda $(\sqrt{ }$ ) yaitu nilai 0 (nol) maka perlu dilakukan tinjauan dan pengkajian ulang terhadap model tes untuk dilakukan revisi. Hasil 
observasi (ya) mendapat nilai 1 (satu) dan hasil observasi tidak mendapat nilai 0 (nol). Hasil penilaian terhadap item-item observasi dijumlahkan, kemudian di total nilainya dikonversikan untuk mengetahui katagorinya.

\section{HASIL PENELITIAN}

Nama instrumen $T$-Test TPS (Tes Mengukur Kelincahan Tendangan dalam Olahraga Pencak silat.

Hasil uji coba kelompok kecil

Tabel 1. Hasil Uji Coba Kelompok Kecil

\begin{tabular}{ll}
\hline \multicolumn{1}{c}{ Statistika } & \multicolumn{1}{c}{ Hasil } \\
\hline Jumlah & 188,72 \\
\hline Rata-rata & 12,58 \\
\hline Waktu Tertinggi & 11,19 \\
\hline Waktu Terendah & 13,60 \\
\hline Standar Deviasi & 0,94 \\
\hline Varians & 0,89 \\
\hline
\end{tabular}

Hasil uji coba kelompok besar

Tabel 2. Hasil Uji Coba Kelompok Besar

\begin{tabular}{ll}
\hline \multicolumn{1}{c}{ Statistika } & \multicolumn{1}{c}{ Hasil } \\
\hline Jumlah & 372,75 \\
\hline Rata-rata & 12,425 \\
\hline Waktu Tertinggi & 13,98 \\
\hline Waktu Terendah & 11,13 \\
\hline Standar Deviasi & 0,88 \\
\hline Varians & 0,78 \\
\hline
\end{tabular}

\section{Uji Validitas dan Reliabilitas}

Validitas instrumen diketahui melalui analisis yang dilakukan oleh expert judgement terhadap bentuk tes kelincahan tendangan Pencak silat. Hasil analisis lembar validasi yang dilakukan oleh kelima judge dinyatakan layak atau valid. Jika dihitung dengan prosentasi yang menunjukan bahwa 100\% expert judgement menyatakan layak terhadap tes kelincahan tendangan Pencak silat.

Reliabilitas pada penelitian ini menggunakan tes ulang. Sedangkan untuk perhitungan analisis statistik dengan menggunakan korelasi dibantu dengan MS Excel. Data yang dikorelasikan untuk membuktikan reliabilitas tes dilakukan dengan cara mengkorelasikan skor tes kelincahan tendangan yang pertama dengan skor tes kelincahan tendangan yang kedua. Diketahui $\mathrm{r}$ tabel $=\mathrm{N}-2=30-2=8 . \mathrm{r}$ tabel $=0,3610$. Karena nilai $\mathrm{r}$ hitung $>\mathrm{r}$ tabel, atau 0,96> 0,3610, maka dapat disimpulkan bahwa variabel antara tes percobaan I dan II memiliki hubungan yang sangat kuat. 
Prosedur tes kelincahan tendangan Pencak silat

Alat: cone, stopwatch, pencing pet, peluit, blangko dan alat tulis.

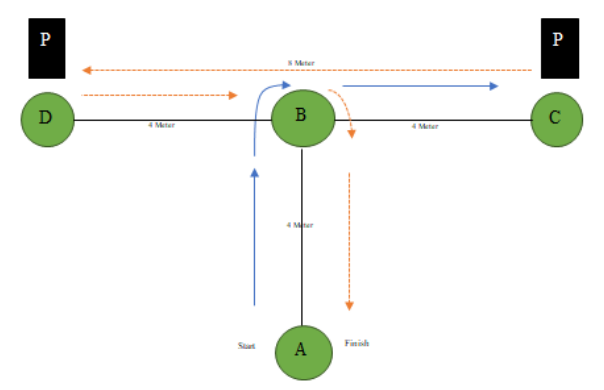

Gambar 2. Produk Akhir

\section{Petunjuk Pelaksanaan:}

1. Testi bersiap-siap berada di posisi garis start/cone A.

2. Ketika ada aba-aba dari pencatat waktu, testi berlari melewati cone B dilanjutkan dengan berlari ke samping kanan menuju cone $\mathrm{C}$.

3. Saat tiba di cone $\mathrm{C}$ testi melakukan tendangan dengan kaki kanan sebanyak 2 kali pada pencing pet/target sasaran yang telah ditentukan.

4. Setelah menendang dilanjutkan dengan testi berlari ke samping kiri melewati cone B dan berhenti di cone D.

5. Di cone D testi melakukan tendangan kaki kiri sebanyak 2 kali pada pencing pet/target sasaran yang telah ditentukan

6. Dilanjutkan step samping kanan menuju cone B kemudian berbalik arah menuju cone A dengan berlari.

7. Stopwatch berhenti setelah testi melewati cone A.

Penilaian

1. Testi dianggap gagal tidak melewati cone atau salah arah

2. Testi dianggap gagal jika tidak melakukan tendangan yang sesuai instruksi

3. Testi diberi 3 kali kesempatan, diambil waktu terbaik dari 3 kali kesempatan tersebut.

4. Setelah 3 kali kesempatan kemudian waktu dicatat dan dijadikan sebagai nilai kelincahan tendangan.

\section{PEMBAHASAN}

Pertandingan Pencak silat adalah pertandingan yang menampilkan dua orang pesilat dari kubu yang berbeda, keduanya saling berhadapan menggunakan unsur pembelaan dan serangan (G. E. Saputro et al., 2018) yaitu menangkis, mengelak, mengena, menyerang pada sasaran dan menjatuhkan lawan, menggunakan teknik dan praktik bertanding, ketahanan dengan stamina serta semangat juang menggunakan kaidah dan pola langkah yang memanfaatkan kekayaan teknik jurus untuk mendapatkan nilai terbanyak.

Teknik serangan dengan tungkai biasa disebut "tendangan", dapat dilakukan dengan berbagai cara dan bentuk sikap kaki (Marlianto et al., 2018) seperti (1) tendangan lurus atau 
lebih dikenal dengan tendangan depan, (2) tendangan samping atau lebih dikenal dengan tendangan T, (3) tendangan busur/melintang atau lebih dikenal dengan tendangan sabit, (4) tendangan belakang, dan (5) lututan yaitu serang dengan menggunakan lutut. Tendangan dalam olahraga Pencak silat merupakan komponen yang paling dominan baik saat melakukan serangan maupun belaan. Pada dasarnya untuk mengetahui bahwa tendangan tersebut mempunyai kualitas yang baik, dibutuhkan suatu alat ukur yang baku dan standar. Alat ukur untuk mengetahui kualitas tendangan belum ada standar baku serta norma penilaiannya. Dengan demikian belum adanya tolok ukur atau alat evaluasi yang digunakan sebagai panduan untuk melihat perkembangan dan peningkatan kemampuan tendangan sebagai wujud dari keberhasilan pencapaian program latihan sebagai akibatnya keberhasilan yang telah dicapai oleh atlet belum dapat terpantau dengan baik.

Berawal dari belum adanya suatu tes kelincahan khusus dalam olahraga Pencak silat, maka peneliti berasumsi akan membuat suatu intrumen tes kelincahan tendangan Pencak silat melalui penelitian pengembangan dari tes kelincahan T-Test yang kemudian dikembangkan menjadi TTest TPS atau tes kelincahan tendangan Pencak silat. Pengertian kelincahan (agility) adalah kemampuan seseorang untuk berlari cepat dengan mengubah-ubah arah. Dalam Pencak silat, dengan memiliki kelincahan yang baik akan memudahkan pesilat dalam serangan atau belaan dengan posisi yang benar. Kelincahan dalam Pencak silat merupakan kemampuan pesilat untuk bergerak cepat dengan posisi yang tepat (benar) dan memberikan landasan yang kokoh saat melakukan serangan maupun belaan.

\section{KESIMPULAN}

Melalui serangkaian hasil penelitian yang sudah dilakukan, peneliti dapat menyimpulkan hasil penelitian yaitu model tes kelincahan tendangan Pencak silat dapat digunakan untuk semua atlet Pencak silat. Implikasinya yaitu: hasil tes dapat menjadi parameter dan acuan pelatih untuk melihat perkembangan atlet tentang kelincahan tendangan Pencak silat. Sehingga perkembangan atlet dapat terpantau dengan benar. Melalui hasil penelitian ini akan berdampak pada pemilihan atlet, sehingga seorang pelatih dapat menentukan kelayakan seorang atlet untuk bertanding atau tidak dari hasil tes kelincahan ini. Adanya peneltian ini perkembangan olahraga Pencak silat diharapkan akan semakin baik dan akan semakin maju sesuai dengan perkembangan teknologi dan pengetahuan.

\section{REFERENSI}

Diana, F. (2019). Pengaruh Metode Latihan Dan Kekuatan Terhadap Tendangan Depan Pencak Silat. Jurnal Ilmu Keolahragaan.

Ediyono, S., \& Widodo, S. T. (2019). Memahami Makna Seni dalam Pencak Silat. Panggung. https://doi.org/10.26742/panggung.v29i3.1014

Hariono, A., Rahayu, T., Sugiharto, \& Sulaiman. (2016). Penyusunan Assessment Performa Tendangan Pencak Silat Kategori Tanding. Sport.

Harun, H., Hidayat, S., \& Hadjarati, H. (2020). Analyze The Speed Of Side Kicks Of Teenage Fighters. Jambura Journal of Sports Coaching, 2(1). https://doi.org/10.37311/jjsc.v2i1.5627

Hausal, H., Lubis, J., \& Puspitorini, W. (2018). Model Latihan Teknik Dasar Serangan Tungkai. 
Jurnal Pendidikan Jasmani Dan Adaptif.

Hidayat, S., \& Kadir, S. (2020). Kontribusi Daya Ledak Otot Tungkai Dan Keseimbangan Terhadap Hasil Tendangan Depan Atlet Pencak Silat Program Studi Pendidikan Kepelatihan Olahraga Fakultas Olahraga Dan Kesehatan Universitas Negeri Gorontalo. COMPETITOR: Jurnal Pendidikan Kepelatihan Olahraga, 10(2). https://doi.org/10.26858/com.v10i2.13188

Marlianto, F., Yarmani, Y., Sutisyana, A., \& Defliyanto, D. (2018). Analisis Tendangan Sabit Pada Perguruan Pencak Silat Tapak Suci Di Kota Bengkulu. KINESTETIK, 2(2). https://doi.org/10.33369/jk.v2i2.8740

Pomatahu, A. R. (2018). The relationship between leg length and crescent kick speed in Pencak Silat sport. Trends in Sport Sciences, 25(2). https://doi.org/10.23829/TSS.2018.25.2-4

Regency, T., \& Sinurat, R. (2020). The Relationship of Agilityagint Crescent Kick to Persaudaraan Setia Hati Athletes in Rokan Hulu Regency. Journal of Physics: Conference Series, 1655(1). https://doi.org/10.1088/1742-6596/1655/1/012067

Saputra, J., Syafrial, S., \& Sofino, S. (2018). Pengaruh Latihan Push - Up Dan Latihan Pull - Up Terhadap Kemampuan Pukulan Lurus Olahraga Pencak Silat Pada Siswa Ekstrakurikuler SMP Negeri 1 Kota Bengkulu. KINESTETIK, 2(1). https://doi.org/10.33369/jk.v2i1.9194

Saputro, D. P., \& Siswantoyo, S. (2018). Penyusunan norma tes fisik pencak silat remaja kategori tanding. Jurnal Keolahragaan. https://doi.org/10.21831/jk.v6i1.17724

Saputro, G. E., Hanief, Y. N., Herpandika, R. P., \& Saputro, D. P. (2018). Modul tutorial sebagai media pembelajaran pencak silat untuk siswa sekolah menengah kejuruan. Jurnal Keolahragaan, 6(2). https://doi.org/10.21831/jk.v0i0.21099

Sayfei, M., Budi, D. R., Himawan Kusuma, M. N., \& Listiandi, A. D. (2020). Identifikasi Keberbakatan Menggunakan Metode Australian Sport Search Terhadap Kesesuaian Cabang Olahraga Pada Anak Sekolah Dasar. Physical Activity Journal, 1(2). https://doi.org/10.20884/1.paju.2020.1.2.2285

Setiawan, I. (2011). Eksistensi Seni Pencak Silat di Kabupaten Purwakarta (Kajian tentang Strategi Adaptasi). Patanjala: Jurnal Penelitian Sejarah Dan Budaya. https://doi.org/10.30959/patanjala.v3i3.254

Subekti, N., Sistiasih, V. S., Syaukani, A. A., \& Fatoni, M. (2020). Kicking ability in pencak silat, reviewed from eye-foot coordination, speed, and ratio of limb length-body height. Journal of Human Sport and Exercise, 15(Proc2). https://doi.org/10.14198/jhse.2020.15.Proc2.36

Tofikin, \& Sinurat, R. (2020). Zig-Zag Run: Metode Latihan Kelincahan Tendangan Sabit Pencak Silat. Journal Sport Area, https://doi.org/10.25299/sportarea.2020.vol5(2).5333

Trisnowiyanto, B. (2016). Latihan Peningkatan Kemampuan Biomotor (Kelincahan, Kecepatan, Keseimbangan Dan Fleksibilitas) Dengan Teknik Lari (Shuttle Run, Zig-Zag, Formasi 8) Pada Pesilat. Jurnal Keterapian Fisik. https://doi.org/10.37341/jkf.v1i2.85 